\title{
A tale of two species: human and peafowl interactions in human-dominated landscapes influence each other's behaviour
}

\author{
Dhanashree Paranjpe* and Priyanka Dange \\ Annasaheb Kulkarni Department of Biodiversity, MES Abasaheb Garware College, Karve Road, Pune 411004 , India
}

\begin{abstract}
Human perception of wildlife, especially attitude towards bird species may vary from non-violent coexistence to a perception of birds as pests and may be an important factor in population management and conservation practices in urban and semi-urban areas. Based on data collected from survey interviews, we studied the perceptions of local communities in Rajasthan, India towards Indian peafowl. Local communities reported Indian peafowl as crop pest and this perception and crop loss varied across seasons. Despite this, locals have a positive perception of Indian peafowl and regularly offered grains for them. Food provisioning by humans influenced diet composition and time-budget of Indian peafowls. Sites at which food provisioning was less or absent, peafowl spent more time in walking and more than $50 \%$ of their diet consisted of natural food. In contrast, at food provisioning sites, time spent in walking was significantly less, while time spent in feeding was significantly more; and over $70 \%$ of their diet consisted of provisioned grains. Food provisioning changed the benefit : cost ratio of behaviours between provision and non-provision sites. Thus, perception of wildlife and food provisioning by humans can change feeding ecology of Indian peafowl populations.
\end{abstract}

Keywords: Benefit : cost ratio, food provisioning, human-wildlife interaction, peafowl, time budget.

WILD animals are increasingly found near human habitation due to scarcity of natural habitats, high human population density and changing landuse ${ }^{1-4}$. As a result, human-animal interactions and conflicts have increased. The impact of wild animals on local human population has mostly been studied in the context of human-wildlife conflicts, where the interactions are costly on both sides, while the impact of local human population on animal populations living close to or within rural, semi-urban and urban areas has rarely been studied in the context of non-violent interactions 5 .

There are potentially diverse types of interactions between humans and wildlife. The impact of human-induced ecological stressors on animal populations in human-

\footnotetext{
*For correspondence. (e-mail: dhana4shree@gmail.com)
}

dominated landscapes is becoming an important area of re$\operatorname{search}^{5,6}$. Wild animals can influence local human population socially, economically through crop loss, property damage, loss of life, ecosystem services and aesthetic/ religious value. They can become sources of income through ecotourism, trade of animal-derived products, etc.

Apart from the impact of wildlife on humans, vicinity to human population can change the natural behaviour and life history of animals in multiple ways. Human habitation or agricultural landscapes can serve as safer refuge areas or even new habitats for wildlife ${ }^{7}$. Humans often provide food to wildlife voluntarily around their homes, or in religious places as a ritual, or in wildlife tourism spots/feeding stations ${ }^{8,9}$. In addition, indirect provisioning in the form of crops, ornamental plants, livestock or waste food thrown in the open becomes an easy and reliable source of food for wildlife. Food provided by humans tends to be calorie-rich, easily digestible, and available at predictable times and places. It is known that food provisioning might change feeding habits, diet preference or diet composition of wild mammals ${ }^{1,6,8-10}$. Reduced predatory pressure and regular availability of nutrient-rich food (in the form of crops) round the year are likely to provide greater resilience of wild animals. It also allows them to live successfully close to agricultural landscape and human habitation ${ }^{1,6,11}$.

There are many avian species like crows, sparrows, pigeons, cranes and egrets that inhabit human-dominated landscapes or stay close to/within human habitation. Appreciation for birds and even individual species may vary from non-violent coexistence (including feeding them) to the perception of birds as pests ${ }^{12}$. There are few studies on how human perception/attitude towards avian species can influence the outcome of their interactions with humans. A multi-dimensional approach to study such interactions is necessary to understand the capacity of local stakeholders to accept wild species ${ }^{13}$, as well as the potential effect of these interactions on both humans and wildlife sharing common spaces.

Indian peafowl (Pavo cristatus) is a species that has co-habited human-dominated landscapes for centuries in its native geographical range. This avian species is native to the Indian subcontinent and has been introduced in 
many parts of the world relatively recently. Although its native habitat is undergrowth in open forests and woodlands near a water body, it is also found near farmlands, villages and has increasingly become common in urban and semi-urban areas ${ }^{14}$. In some places, such as Morachi Chincholi, Maharashtra, India, 'eco-tourism' based on Indian peafowl is flourishing and this is an additional or alternative source of income for the local community (pers. observ.). In contrast to this 'positive' impact, anecdotal reports suggest that the Indian peafowl can cause substantial crop losses in areas where its population density is high ${ }^{15}$. There are no known studies from India that estimate crop losses due to peafowls. It is not known whether peafowl really affect crops like other known crop pests (e.g. wild boar, elephants, deer, etc.). Numerous media reports can be found on the death of individual or groups of peafowls in India, may be due to natural reasons such as predation, water scarcity or the result of unintentional poisoning due to insecticides/pesticides sprayed on crops that the peafowls feed on. Intentional killing of peafowls by certain tribal communities for their ornamental feathers and meat has also been suspected/reported. In contrast, in some parts of the country (e.g. Rajasthan), peafowls are believed to be sacred and people actively offer grains to them as part of their daily ritual. These varied interactions between Indian peafowl and local human population make it an interesting study system to understand consequences of human-wildlife interactions. It remains to be seen how common are the positive perceptions and associated beliefs/rituals throughout the region in which the population density of Indian peafowl is higher. Can these perceptions result in curbing population decline or effective management/conservation of the species? To address these questions, we studied three aspects of humanpeafowl interactions in detail. The objectives of this study were: (i) to understand the perceptions of local communities about Indian peafowl; (ii) to estimate the impact of Indian peafowl populations on local agriculture as perceived by the local communities and (iii) to estimate the impact of food provisioning by local communities on peafowl populations.

\section{Materials and methods}

\section{Study area}

We selected three field sites - Morachi Chincholi and Nashik in Maharashtra and sites around Ranthambhore Tiger Reserve (RTR) in Rajasthan (Table 1). Selection of study areas was based on several criteria such as their closeness to human habitation, accessibility throughout the year, history of peafowl populations in the area, potential interactions between humans and peafowl (food provisioning, peafowls visiting/roosting on agricultural lands and village homes, sale of peafowl feathers or related 'products', tourism, cultural significance), etc.
Sites located outside Protected Areas (PAs) and close to human habitation were given preference.

We used questionnaire-based interviews $(N=196)$ to estimate impact of Indian peafowl populations on local agriculture and to understand perceptions of local people about peafowls in four villages located on the periphery of RTR, Rajasthan. Interviews were conducted by taking the family as a unit respondent. The questionnaire included fixed and open-ended questions (see Supplementary 1 for the complete questionnaire). Interviews began with the interviewer clearly explaining the objectives of the study and the interview was continued only if the respondent(s) gave their consent. The questionnaire consisted of three parts: (i) Basic information about the respondents such as name, age, address, number of people in the family unit, source(s) of income (agriculture/others). (ii) Questions related to perceived impact of peafowls on agriculture. (iii) Questions related to social/cultural/ traditional perceptions about the Indian peafowl. Interviews were conducted in three different seasons: November 2016 (harvest time for kharif crops, winter season, $N=55$ ), March-April 2017 (harvest time for rabi crops, beginning of dry summer season, $N=86$ ), July-August 2017 (standing crops, monsoon season, $N=55$ ) to check if responses to some of the questions related to agriculture differed according to stage of crop/season. For each survey season, respondents were sampled randomly from the local village populations in proportion to the number of family units (10\% of total family units) in the village. So a small fraction of the respondents was selected more than once, while others were unique. Surveys with incomplete responses recorded were excluded from analysis.

To estimate the impact of food provisioning by local communities on peafowl populations, behaviours of the birds were studied throughout the year using direct field observations during morning (6-10 am) and evening (47 pm). During October 2016 to August 2018, approximately more than 217 hours of field observations were made to record peafowl behaviours (34 morning sessions of $4 \mathrm{~h}$ each, 27 evening sessions of $3 \mathrm{~h}$ each and six occasions of afternoon observations spread over 37 days at three different study sites). Behaviours were also observed in the late afternoons if peafowls were found to be active. The observations were recorded while patrolling the study area using continuous scan and focal animal sampling. Focal animals were chosen randomly from a group (if the peafowls were seen in a group). Behaviours of focal animals were recorded continuously without disturbing or going too close to them (typically from a distance of 10-100 m) until they were out of sight. The location of observation was recorded as food provisioned or non-provisioned site. Gender of the focal animal was noted along with the date, place (field site) and total duration of observations. Data were also collected using binoculars about the type of food the birds ate. 
RESEARCH ARTICLES

Table 1. Brief description of study areas

\begin{tabular}{|c|c|c|}
\hline Study area & GPS coordinates & Brief site description \\
\hline Morachi Chincholi, Maharashtra & $18^{\circ} 48^{\prime} 26.9^{\prime \prime} \mathrm{N}, 74^{\circ} 09^{\prime} 29.3^{\prime \prime} \mathrm{E}$; elevation $641 \mathrm{~m}$ amsl & Village, agricultural lands, dry deciduous hillock \\
\hline \multicolumn{3}{|l|}{ Nashik, Maharashtra } \\
\hline Ganagpur Nursery, Gangapur dam & $20^{\circ} 02.109^{\prime} \mathrm{N}, 73^{\circ} 40.970^{\prime} \mathrm{E}$; elevation $611 \mathrm{~m}$ amsl & Plantation, agricultural fields, big water reservoir \\
\hline MERI Campus, Nashik city & $20^{\circ} 01^{\prime} 11.0^{\prime \prime} \mathrm{N}, 73^{\circ} 48^{\prime} 04.0^{\prime \prime} \mathrm{E}$; elevation $404 \mathrm{~m}$ amsl & Plantation \\
\hline \multicolumn{3}{|l|}{ Sawai Madhopur, Rajasthan } \\
\hline Kutthalpura & $26^{\circ} 03^{\prime} 58.5^{\prime \prime} \mathrm{N}, 76^{\circ} 26^{\prime} 13.4^{\prime \prime} \mathrm{E}$; elevation $261 \mathrm{~m}$ amsl & Dry deciduous forest, agricultural farms \\
\hline Bangadda-Kalan & $26^{\circ} 3^{\prime} 57.78^{\prime \prime} \mathrm{N}, 76^{\circ} 42^{\prime} 35.76^{\prime \prime} \mathrm{E}$ & Village, agricultural fields \\
\hline Sanwata-Kalakhora & $26^{\circ} 6^{\prime} 41.46^{\prime \prime} \mathrm{N}, 76^{\circ} 38^{\prime} 33.81^{\prime \prime} \mathrm{E}$; elevation $267 \mathrm{~m}$ amsl & $\begin{array}{l}\text { Remote village with agricultural fields, dry } \\
\text { deciduous forest }\end{array}$ \\
\hline Govindpura & $26^{\circ} 04.826^{\prime \prime} \mathrm{N}, 76^{\circ} 48.097^{\prime \prime} \mathrm{E}$; elevation $227 \mathrm{~m}$ amsl & Village, agricultural fields \\
\hline
\end{tabular}

Table 2. Diet composition (presence/absence of provisioned and non-provisioned food) of Indian peafowl Pavo cristatus at three sites based on direct field observations

\begin{tabular}{|c|c|c|c|c|c|}
\hline Diet & Food category & Natural/provisioned food & Morachi Chincholi & Nashik & Sites around RTR \\
\hline Sorghum (Sorghum spp.) & Cereals & $\mathrm{P}$ & 1 & 0 & 0 \\
\hline Wheat (Triticum spp.) & Cereals & $\mathrm{P}$ & 1 & 1 & 1 \\
\hline Bajra (Sorghum spp.) & Cereals & $\mathrm{P}$ & 1 & 0 & 1 \\
\hline Rice (Oryza sativum) & Cereals & $\mathrm{P}$ & 1 & 1 & 1 \\
\hline Corn (Zea mays) & Cereals & $\mathrm{P}$ & 1 & 0 & 0 \\
\hline Unknown grains & Cereals & $\mathrm{P}$ & 1 & 0 & 0 \\
\hline Methi grass & Non-grain & $\mathrm{N}$ & 1 & 0 & 0 \\
\hline Insects & Non-grain & $\mathrm{N}$ & 1 & 1 & 1 \\
\hline Leaves/grass & Non-grain & $\mathrm{N}$ & 1 & 1 & 1 \\
\hline Seeds & Non-grain & $\mathrm{N}$ & 0 & 1 & 0 \\
\hline Chillies (Capsicum annum) & Non-grain & $\mathrm{P}$ & 1 & 0 & 1 \\
\hline Vegetables & Non-grain & $\mathrm{P}$ & 1 & 0 & 0 \\
\hline Unknown (non-grain) & Non-grain & $\mathrm{N}$ & 1 & 1 & 1 \\
\hline Green gram (Vigna radiata) & Pulses & $\mathrm{P}$ & 1 & 0 & 1 \\
\hline Split pigeon pea (Cajanus cajan) & Pulses & $\mathrm{P}$ & 0 & 0 & 1 \\
\hline Black gram lentil (Vigna mungo) & Pulses & $\mathrm{P}$ & 1 & 0 & 0 \\
\hline Moth beans (Vigna aconitifolia) & Pulses & $\mathrm{P}$ & 1 & 0 & 0 \\
\hline Black eyed pea (Vigna unguiculata) & Pulses & $\mathrm{P}$ & 1 & 0 & 0 \\
\hline Chickpea (Cicer arietum) & Pulses & $\mathrm{P}$ & 1 & 0 & 0 \\
\hline Peanuts & Pulses & $\mathrm{P}$ & 1 & 0 & 0 \\
\hline
\end{tabular}

Observations were stopped when the focal animal flew/walked out of the observer's sight.

For calculating time budget of the Indian peafowl populations, the observer(s) documented start/end/ transition of behaviours of the focal animal as a running commentary using a handheld digital audio recorder (SONY ICD-UX560F). Occasionally, data were recorded as videos using a camcorder (Panasonic, Full HD, $29.8 \mathrm{~mm}$ wide 20.4 megapixel HC-X920), if a large group of peafowls was found near the feeding site.

\section{Data processing}

The type of food items peafowls ate was listed using direct observations (Table 2). Cereals, pulses, vegetables and processed food were available to peafowls only around human habitation and hence were considered as provisioned food, while all other food items such as grass, leaves, sprouts, fruits, seeds, insects and worms were considered as natural food items (Table 2). Based on direct observations of peafowls eating various food items, the proportion of natural and provisioned food items in their diet was calculated. If it was not clear what the peafowls were eating, such observations were not considered for further analysis. The food items were further categorized as cereals (grains such as sorghum, wheat, bajra, rice, corn, etc.), pulses (split pigeon peas, black gram lentil, black-eyed pea, Indian brown lentil, green gram, peanuts, etc.), non-grains (fruits, grass, seeds, leaves, insects, vegetables, etc.), and processed food. The number of times peafowls were seen eating 


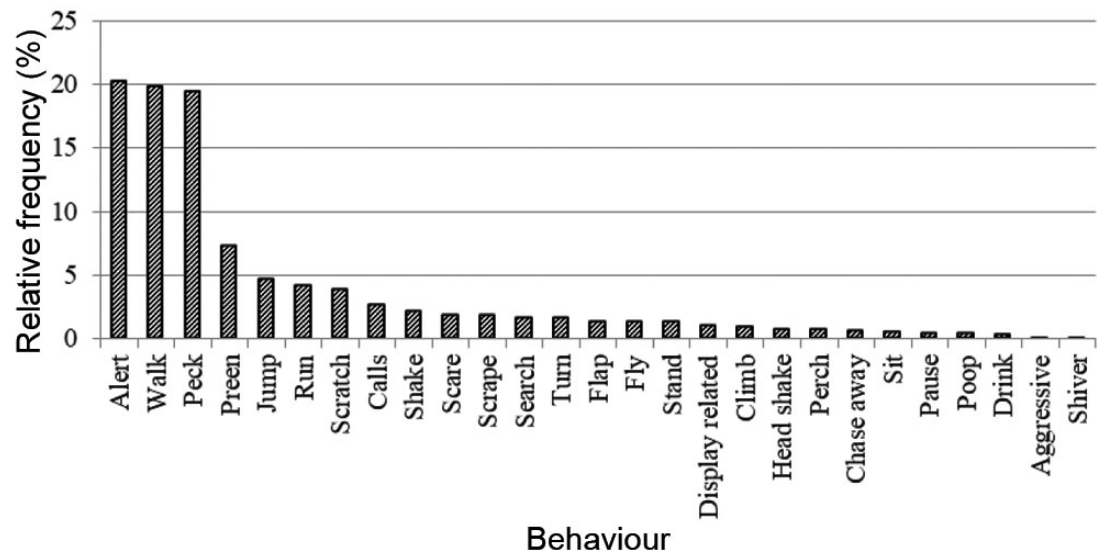

Figure 1. Ethogram of behaviour of Indian peafowl across all field sites.

each food type was counted. Based on this frequency, the percentage of each food type in their diet was calculated.

Figure 1 shows the ethogram of peafowl behaviour using the scan data (see Supplementary 2 for a description of behaviours). Relative frequency of each behaviour recorded for 293 individuals was calculated as ((no. of times a behaviour is shown/total number of observations $) \times 100$ ) to identify the major and minor behaviours of Indian peafowl. Peck, alert and walk were the major behaviours, while the minor ones ( $<10 \%$ frequency) were pooled as other behaviours. For calculating time budget of Indian peafowl populations, time at the beginning of a behaviour and at the end of a behaviour/transition to another behavioural state was noted down for each focal animal from the audio records. This was used to calculate the time spent in various activities/behaviours for each recorded individual. Fraction of time spent in each activity was summed across all individuals in the population. Time budget of the whole population was calculated as time spent in each activity divided by the total time of observations for the population.

For calculating benefit : cost ratio, time spent in feeding was considered as 'benefit' while time spent in all other activities (except standing inactive) was considered as 'cost'.

\section{Statistical analysis}

For statistical analysis, STATISTICA ${ }^{\mathrm{TM}}$ software version 13.2 (Dell Inc. USA, 2016) was used. As the data did not follow normal distribution, non-parametric tests were used for further analysis. Kruskal-Wallis ANOVA was used to examine the effect of field sites (Morachi Chincholi, Nashik, Rajasthan) and sex (male, female) on time spent in feeding, time spent in vigilance, walking and other behaviours. Mann-Whitney $U$ test was used to estimate the effect of proximity to food provision site on time spent in feeding, vigilance, walking and other behaviours.
Benefit : cost ratio was compared across the three field sites (Morachi Chincholi, Nashik, Rajasthan, KruskalWallis test), and between food provision and nonprovisioning sites using non-parametric tests such as Mann-Whitney $U$ test.

\section{Results}

\section{Perceptions about Indian peafowl and its relation to agriculture}

The age of survey respondents varied from 15 to 65 years; all age classes in this range were represented almost equally. Respondents included $90.73 \%$ males and $9.27 \%$ females. Sources of income of the respondents included agriculture ( $51.32 \%$ of respondents), animal herding (17.88\%), labour (farm or other labour, 20.2\%) and other sources $(10.6 \%)$ such as contractor, company job, mechanic, shop owner, artisan, teacher, etc. Majority of farmers in the area around RTR were smallholder farmers with $84.11 \%$ of them owning less than 5 acres of land, while rest of the farmers $(15.89 \%)$ owned 5-20 acres of land. Farmers cultivated two to 16 types of crops in a year depending on the size of their farm, availability of labour, water, etc. The most common crops in this region included wheat, bajra, chilly, mustard, sorghum and sesame. All farmers in the region reported crop loss, irrespective of time of the year during which the survey was conducted. The reasons for crop loss differed according to the season during which the interviews were conducted. Table 3 provides details of season-wise reasons for crop loss. Major crop pests reported in the survey were wild boar (Sus scrofa), Nilgai/blue bull (Boselaphus tragocamelus), Indian peafowl ( $P$. cristatus) and deer. However, the number of respondents reporting particular types of crop pests changed according to the season in which the surveys were conducted (Figure 2). Although Indian peafowl is the third common crop pest reported, only $2.84 \%$ of respondents in the November 2016 survey 

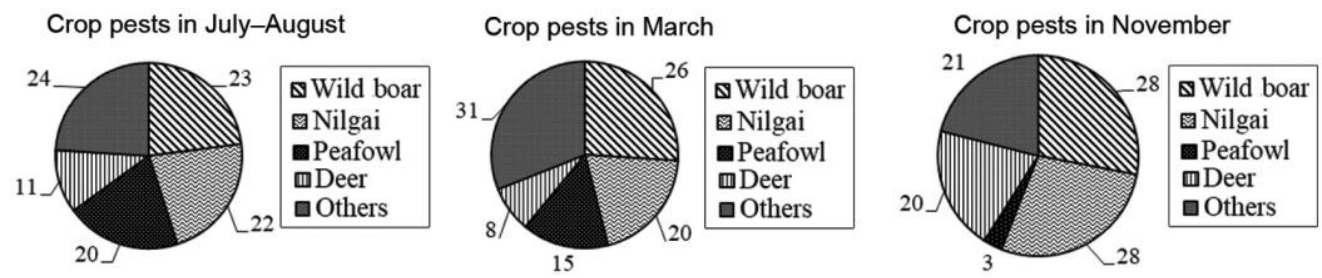

Figure 2. Percentage of respondents reporting crop pests during November, July-August, and March in sites around RTR.

Table 3. Typical reasons of crop loss in Ranthambhore Tiger Reserve (RTR) region of Rajasthan

\begin{tabular}{lccc}
\hline Reasons for crop loss & $\begin{array}{c}\text { July-August } \\
(\%)\end{array}$ & $\begin{array}{c}\text { March } \\
(\%)\end{array}$ & $\begin{array}{c}\text { November } \\
(\%)\end{array}$ \\
\hline Crop pests & 62.34 & 59.82 & 100.00 \\
Untimely rainfall & 36.36 & 31.25 & 0.00 \\
Disease & 1.30 & 8.93 & 0.00 \\
\hline
\end{tabular}

Table 4. Agricultural land use by Indian peafowl in the RTR region of Rajasthan

\begin{tabular}{lc}
\hline Peafowl activities on the farm & Percentage of respondents \\
\hline Eat harvest & 42.67 \\
Eat leaves & 17.00 \\
Eat insects & 19.67 \\
Drink water & 6.67 \\
Eat flowers & 8.00 \\
Eat seeds & 0.67 \\
Eat sapplings & 3.67 \\
Nothing & 1.33 \\
Spread disease & 0.33 \\
\hline
\end{tabular}

mentioned it was a crop pest compared to $15.16 \%$ respondents in March 2017 and 19.7\% respondents in July 2017. On the other hand, wild boar and blue bull were reported as crop pests throughout the year by 19 $28 \%$ respondents (the range reflects variation in data collected in different seasons and villages in the study area).

When asked specifically whether Indian peafowl affects crops, 87.6-95.45\% of respondents gave an affirmative reply during the year around survey. According to the respondents, peafowls used agricultural land for feeding and as a source of water (Table 4). Some of the respondents $(0.33 \%)$ also mentioned that they spread diseases. Between $67.65 \%$ and $100 \%$ respondents reported that the long train of feathers causes some damage to crops when the males with full grown train walk through the standing crops. Estimates of total loss due to peafowls varied between $0 \%$ and more than $20 \%$ according to the season in which the surveys were conducted (Figure 3). Chickpea, chilli, wheat and mustard were the major crops that incurred loss due to peafowls. Loss was also reported occasionally for coriander, sorghum, sesame, tomatoes, green peas and moong (all reported by $10 \%$ or less respondents). Indian peafowl ate crops at post-growth (around harvest) stage according to 60-95\% of respondents; the next most vulnerable stage was the pre-growth stage (freshly sown, sprouted or sapling stage) according to $2.5-29.27 \%$ of responses. Damage to crops was reported least in the growth stage (0-9.76\% respondents, Figure 4). Only a few respondents reported damage to crops at all stages (2\%), and no loss due to peafowls (2\%) (Figure 4). Between $64.65 \%$ and $100 \%$ farmers reported that they changed crop pattern to reduce loss due to peafowls. Many farmers chose a different variety of crop that was less preferred by peafowls (e.g. hybrid chilli instead of indigenous variety), or avoided taking certain crops (e.g. chickpea, groundnut, chilli), or changed the location of crop cultivation if they owned more farmlands within the village. Interestingly, the estimated percentage of loss due to Indian peafowl showed positive correlation with size of farm (Spearman rank order correlation $r=0.24, P<0.05)$. Farmers with more farmlands estimated more crop losses due to peafowls compared to those who owned less land.

\section{Food provisioning for Indian peafowl}

In spite of crop damage caused by the peafowls, local people offer them grains throughout the year. All households (100\% respondents) in the village offered grains to peafowls, except during November, when slightly less number of respondents $(94.87 \%)$ reported offering grains to them. The most common grains offered included bajra (35-45\% respondents), sorghum (27.5-41.25\% respondents), wheat (10-25.95\% respondents) and lentils (0$7.57 \%$ respondents), while some also offered rice, maize and sesame when available. People typically offered a handful (100-130 g depending on type of grain) up to even $3 \mathrm{~kg}$ grains at a time. In some villages, grains were offered from each household every day; in some cases they were offered in temples once or twice a week, or on special days/occasions. So year round, on an average $\sim 15 \mathrm{~kg}$ grains is made available for wildlife every day in and around temple premises in the RTR region.

\section{Impact of food provisioning on peafowl populations}

Impact of food provisioning was studied in the three study areas - Morachi Chincholi, Nashik and Rajasthan (RTR). Diet composition of peafowls was different in the 
selected study areas. Based on \% feeding frequency on food type, peafowl diet in Morachi Chincholi consisted of $71 \%$ food provisioned by humans compared to $61 \%$ in Rajasthan, while just $40 \%$ peafowl diet in Nashik consisted of provisioned food (Figure 5). Peafowls in Nashik were seen eating natural (non-grain) food items with almost double the frequency (60\%) compared to those in Morachi Chincholi (29\%). Major portion of food provided to peafowl populations in Morachi Chincholi and Rajasthan consisted of grains $(65 \%$ and $58 \%$ respectively). Peafowls in Rajasthan were not seen eating processed food as opposed to those in Morachi Chincholi and Nashik (Table 5).

There was a lot of variation in the total duration of observations for each individual (range: 1-29 min.). However, total observation time did not differ significantly across field sites (median test, $\chi^{2}=1.75, \mathrm{~d} f=2$, $p=0.42$ ), which confirms that equal efforts were put into observations at the selected field sites. However, frequency of sighting males was significantly greater compared to

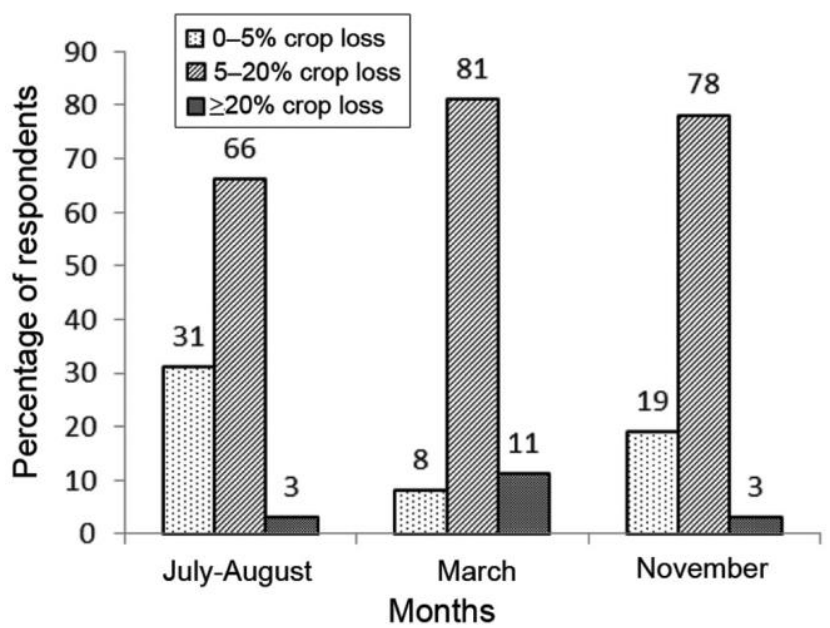

Figure 3. Percentage of respondents reporting crop loss (in \%) due to peafowls during July-August, March and November in sites around RTR, Rajasthan.

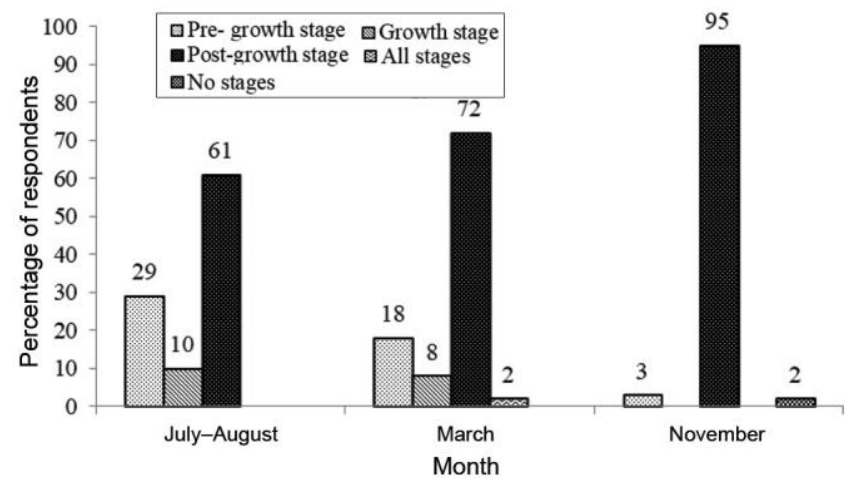

Figure 4. Percentage of respondents reporting stage of crop affected due to peafowls during July-August, March and November in sites around RTR, Rajasthan. frequency of sighting females $(Z=-3.06 P=0.002)$. Figure 6 shows the relative proportion of time spent in different behaviours at food provision sites (where humans offered grains to peafowls) and non-provisioned sites. Time spent in vigilance $(21.88 \%)$ and other behaviours $(8.98 \%)$ at provision sites was comparable to that in nonprovision sites $(30.43 \%$ and $14.26 \%$ respectively; Figure 6). At food provision sites $(N=181)$, individuals spent significantly less time in walking (18.41\%) compared to the non-provision sites $(N=99,22.99 \%$, MannWhitney $U$ test, $P=0.003$; Figure 7). Peafowls spent

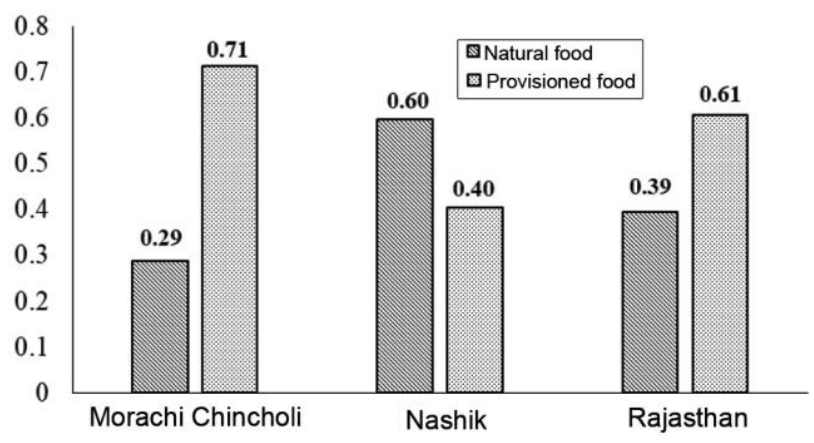

Figure 5. Proportion of natural versus provisioned food items in the Indian peafowl diet across study areas.

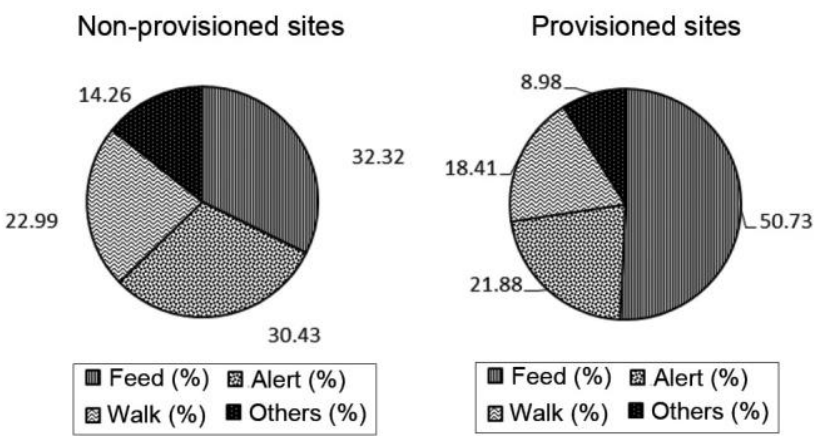

Figure 6. Time budget of Indian peafowl populations at food provisioned and non-provision sites.

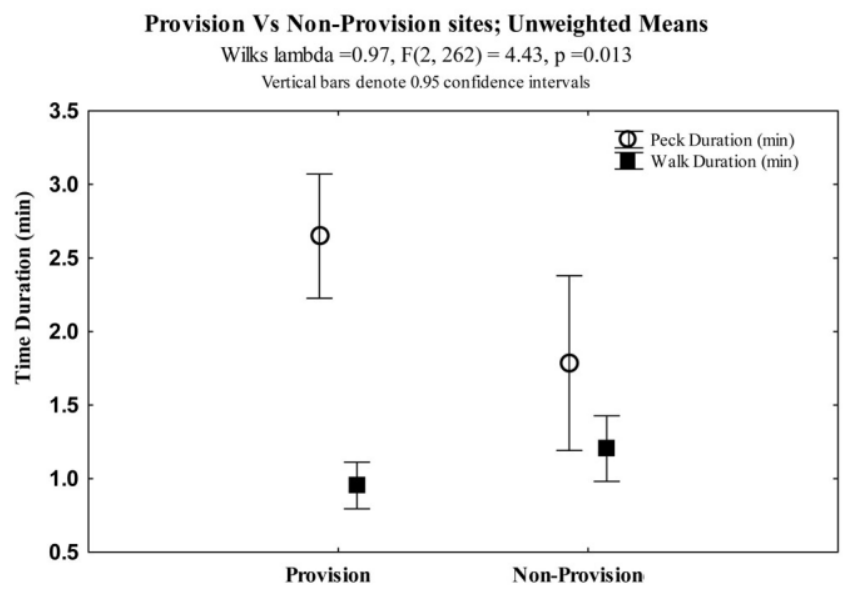

Figure 7. Comparison of time spent in pecking and walking at food provision and non-provision sites. 
Table 5. Diet composition (\%) of Indian peafowl across field sites

\begin{tabular}{lcccc}
\hline Field site & $\begin{array}{c}\text { Cereals } \\
(\% \text { provisioned })\end{array}$ & $\begin{array}{c}\text { Pulses } \\
(\% \text { provisioned })\end{array}$ & $\begin{array}{c}\text { Processed } \\
(\% \text {; provisioned })\end{array}$ & $\begin{array}{c}\text { Non-grain } \\
(\% ; \text { non-provisioned })\end{array}$ \\
\hline Morachi Chincholi & 66 & 3 & 1 & 30 \\
Nashik & 38 & 0 & 2 & 60 \\
Sites around RTR, Rajasthan & 58 & 3 & 0 & 39 \\
\hline
\end{tabular}

significantly more time in feeding $(50.73 \%)$ at the food provision sites compared to non-provision sites $(32.32 \%$, Mann-Whitney $U$ test, $P=0.0003$ ) (Figure 7). Time spent in other behaviours was significantly more at Nashik $(N=59)$ compared to Morachi Chincholi $(N=139)$ and Rajasthan $(N=88$; Kruskal-Wallis ANOVA, multiple comparison of means, $P=0.03$ ).

Benefit: cost ratio measured in terms of time spent in feeding (benefit) versus other behaviours (cost) was significantly different between food provision and nonprovision sites (Mann-Whitney $U$ test, $P=0.00015$ ). The ratio was similar across field sites (Kruskal-Wallis ANOVA, $P=0.22$ ).

\section{Discussion}

Human-wildlife interactions have mostly been studied so far in the context of human-animal conflict which has drastic consequences such as loss of property, crops or even death of livestock and/or humans. All humanwildlife interactions do not necessarily lead to obvious conflicts. Nonetheless, they might impact both players in significant ways. Peoples' perception about wildlife can potentially influence the long-term outcome of such interactions. This study examined in detail some aspects of non-violent human-wildlife interactions by focusing on Indian peafowl populations living in human-dominated landscapes. Our survey covered the perceptions about Indian peafowl in a wide range of age groups (15-65 years) in a geographic area with high population density of these birds. In most cases, the head of the family along with one or two other members (male/female) present in a household answered our survey questions. Therefore, the number of female respondents in our survey remained below $10 \%$. As a result, the conclusions about perceptions may be male-biased.

\section{Perceptions about peafowls and their relation to agriculture}

We did not want to influence the respondents by directly asking them if peafowls damaged their crops. Hence, we asked questions step-by-step about types of crops and typical reasons for crop loss in the RTR area. Erratic rainfall patterns (deficient rainfall, flooding or water clogging, untimely rainfall) are the main reason for crop losses in Indian agriculture which depends largely on monsoon rainfall. Surprisingly, damage due to crop pests emerged as the topmost reason across all seasons for losses to farmers in the RTR area, followed by losses due to untimely rainfall, crop disease, or any other reasons (Table 3). Our survey areas included buffer zone and villages just outside the Ranthambhore National Park. As a result, wild herbivores from the Protected Area frequently enter the villages, farmlands and surrounding areas. This can create serious problems for the farmers whose livelihood depends on agricultural produce. Crop raiding by wild herbivores has been reported from all over the world $^{16-20}$, including India ${ }^{21-24}$. There are sporadic media reports and anecdotal information from different parts of the country about Indian peafowl damaging $\operatorname{crops}^{15}$. However, there has been no systematic survey or documentation of the extent and type of crop damage by Indian peafowl. Recently, Indian peafowl was reported as a crop pest by farmers in Sri Lanka ${ }^{7,20}$. A study reported that Maavee paddies and surrounding habitats offer refuge for wildlife, including Indian peafowl; which damaged rice at the seedling and grain-filling stage irrespective of the farming method used ${ }^{7}$.

Peafowls used agricultural land as a source of food, water (Table 4), display sites and resting sites (pers. obs.). Typically, between $5 \%$ and $20 \%$ loss was mentioned by respondents for various crops. It is important to note that these are 'perceived' estimates of loss given by farmers and the actual figures need to be verified through a more detailed 'on-field' data collection. Other wild herbivores such as elephants can cause up to $35 \%$ crop damage ${ }^{23}$, while wild boars can destroy 5-36\% of crops $^{22}$. Blue bull had the highest impact with $58 \%$ losses (rarely less than 10\%) in Haryana ${ }^{21}$. Losses due to blue bull could be as high as $70 \%$ in high-density areas ${ }^{24}$. Comparatively, 5-20\% loss due to Indian peafowl seems less. Nevertheless, it may be considerable to small farmers in the RTR area. Chickpea, chilli, wheat and mustard (17-50\% respondents for each crop) are the crops preferred by Indian peafowl compared to tomato, sesame, coriander, sorghum, green peas and moong (less than $10 \%$ respondents).

Peoples' perception about Indian peafowl being a crop pest changed according to the season in which they were interviewed. While wild boar or blue bull was consistently reported as crop pest throughout the year, only $2.84 \%$ 
respondents mentioned Indian peafowl as a crop pest in November and as many as $19.7 \%$ respondents called it a crop pest in July 2017. In July and August, various crops are in the growth stage. Our survey also indicates that crops around harvest stage (not growth stage) are most likely to be eaten by Indian peafowl followed by pre-growth stage (freshly sown, sprouted or sapling stage). Least damage is incurred due to peafowls visiting the growing crops (between saplings and seed set) (Figure 4).

The crop damage at different stages of growth may lead to different amounts of loss. Some of the damaged parts may regenerate, but there is substantial amount of loss in terms of total yield ${ }^{25}$. In contrast, for some crops such as chickpea, herbivory in the first 20 days after sowing may actually lead to greater branching resulting in more number of seeds. However, herbivory beyond a threshold in pre-flowering stage is known to decrease crop yield even in chickpea by as much as $67 \%$ (ref. 25).

Many farmers have adopted different strategies to reduce crop loss due to peafowls. These include guarding the farms during most vulnerable stages, changing crop variety or farming location. The effectiveness of these strategies needs to be checked thoroughly. Nonetheless the strategies to reduce crop damage/loss themselves cost the farmers in terms of time, resources and money invested not to mention the inconvenience and loss incurred due to less than optimal choice of crop or farming location.

Overall, the effects of crop damage due to Indian peafowl may vary with the type of crop, season, etc. There is no denying that Indian peafowl seems to be a crop pest at least in some parts of the country. Surprisingly, most respondents in our survey did not have negative views or resentment about Indian peafowl damaging/eating their crops. Many of them, in fact, mentioned that even peafowls have the 'right-to-live' and farmers do not consider it a 'loss' if peafowls eat their crops. It is possible that the 'perceived beauty' of the peafowl along with its association with popular deities in India ${ }^{26}$ and relatively less amounts of crop damage by this species may play a role in biasing the perception of people favourably towards it compared to other crop pests. This seemingly positive perception is in sharp contrast to farmers' perceptions when other crop pests such as wild boar, elephant or blue bull visits their crops. Most of the households in the RTR area in fact proactively offer grains to peafowls throughout the year $(94.87-100 \%$ respondents). Typically bajra, sorghum, wheat or lentils are offered by each household in a designated place around temple premises in the RTR region. The quantity or frequency with which each household offers grains may vary from place to place, but on an average about $15 \mathrm{~kg}$ of grains is offered daily at these designated places in the RTR region as part of temple ritual/traditional belief. As a result, such places have become a reliable source of food for wildlife, including Indian peafowl. Thus, people's positive/neutral perception about Indian peafowl, traditional beliefs and ritual practices such as active food provisioning at temples may be important for maintaining high population of peafowls in the RTR area. One can conclude that human-wildlife interactions and people's perception/attitude towards wildlife can impact not only food provisioning but also wildlife management ${ }^{27,28}$, conservation efforts ${ }^{29}$ and ultimately human-wildlife relationships ${ }^{30}$.

\section{Effects of food provisioning on peafowl populations}

All around the world humans have provided many novel and reliable food resources to herbivores in the form of crops and ornamental plants. Some species exploit these resources quite well and can become economically important crop pests ${ }^{6}$. Generalist herbivores (those who feed on a broad range of plant species) are more likely to exploit the novel food resources (crops, ornamental plants) present in the human-dominated landscapes. Peafowls generally have a broad range of diet options, including plant parts (fresh sprouts, leaves, flowers, fruits, seeds) as well as insects, worms and sometimes small reptiles ${ }^{31}$. In spite of having most of these diet options available in our study areas, peafowls were found eating food provided by humans (cereals, pulses, processed food). According to our estimate, $\sim 30-35 \mathrm{~kg}$ foodgrains are being offered to peafowls per day in the village and surrounding areas of Morachi Chincholi, while $\sim 15 \mathrm{~kg}$ grains is offered per day around homes and temple premises in the villages in Rajasthan included in this study. In both these study areas, grains were offered at designated places every day throughout the year. Thus, Indian peafowl population in Morachi Chincholi has access to diet rich in carbohydrates (cereals) and proteins (pulses) throughout the year (Table 2). As a result, $71 \%$ of the time they were seen eating food provisioned indirectly in the form of crops or directly as grains offered in the village surroundings (Figure 5). Villages in Rajasthan offered relatively less variety of cereals and very few pulses; yet peafowls in Rajasthan were seen eating food provisioned by humans $61 \%$ of the time versus $39 \%$ natural food. The peafowl population in Nashik, on the other hand, has access to less reliable and less varied food offered by humans $(\sim 3-5 \mathrm{~kg}$ per day). As a result, only about $40 \%$ of the time they were seen eating provisioned food. It is argued that crop varieties are rich in nutritional quality and poor in secondary metabolites compared to their wild counterparts ${ }^{32}$. If this is true, it could explain why peafowls are choosing harvested/unharvested crops and ready-to-eat grains/food, wherever they are available, over their 'natural food'. The quantity, variety and nutritional quality of food available to peafowls plus the 
reliability of such food resources might be crucial factors in making food choices and in overall diet composition (Table 5).

Food provisioning not only influenced the diet composition of peafowls, but also the time budget. At food provision sites, the peafowls could spend up to $50.73 \%$ of their time just eating, which is significantly higher than the time spent in feeding at other sites (Figures 6 and 7). They could get high-quality food in one place without spending much time walking. In contrast, they had to spend more time walking in search of food, at nonprovision sites, while they could spend only $32.32 \%$ of their time in feeding (Figure 6). Effect of less amount of food provisioning at Nashik compared to Morachi Chincholi and Rajasthan is reflected in more time spent by peafowls in other behaviours in the former location. Our results suggest that the benefit : cost ratio in terms of time spent in behaviours can be influenced by food provisioning. We could not calculate benefits and costs in terms of energy budget as it was difficult to estimate energy gain from non-provisioned food items such as leaves, insects, sprouts, etc.

Effects of food provisioning on time budget, diet and activity seen in Indian peafowl populations are similar to those seen in primate populations ${ }^{33-38}$. Interestingly, these effects extended to the ranging patterns, foraging success, and consequently fitness of the primates ${ }^{39,40}$. Foodprovisioned primate troops also had higher growth rates and population densities ${ }^{41,42}$. Comparable studies on birds, however, are rare especially in the Indian subcontinent. The present study has documented the effects of food provisioning on feeding ecology of big birds such as Indian peafowl.

Supplementary food available at bird feeders (typically in Western countries) is known to have far-reaching consequences on avian ecology in terms of increasing survival during overwintering, enhanced breeding success, changing sex ratios of offspring in smaller avian species and range expansion of species ${ }^{8}$. Although most of these consequences are positive, some negative consequences of food provisioning are also possible in avian as well as primate species. If animals start depending on food provided by humans, it may lead to behavioural changes as illustrated in Finland, where some great-tit populations are so dependent on supplementary food during winter that they can no longer be sustained by natural food resources alone ${ }^{43}$. In Morachi Chincholi, where large amounts of grains are provisioned throughout the year, a somewhat similar scenario exists during summer months. In April, May and a part of June, the temperature is high (up to $42^{\circ}-45^{\circ} \mathrm{C}$ ) and water is scarce. If there are no crops during summer months in a particular year, the peafowls concentrate around the remaining waterbodies (village wells, ponds) and wherever humans provide them grains and water (per. obs.). Although it is not surprising that peafowls incorporate nutrient-rich resources in their diet wherever such an option is available, it is interesting that these resources are being actively provided to them by humans in at least some places. It may, thus, be important to factor in human attitude towards this species in population management or future conservation efforts, especially considering how frequently peafowls are found in human-dominated landscapes.

The dynamic interplay of experiential, ecological, socio-economic and cultural factors can influence perception and local human behaviour towards wild species with significant implications for their management and the ecosystems they inhabit ${ }^{44}$. Studies such as ours may help in designing effective conservation strategies for species.

\section{Conflict of interest. Authors declare no conflict of} interest.

Permissions. No live animals/samples were handled during this study. The study was conducted outside protected areas and therefore did not require special permissions.

1. Ayyappan, S., Agrawal, P. K., Rao, V. V. and Tripathi, R. S., Human-wildlife 'conflict to coexistence' in agro-pastoral landscapes. In Human Animal Conflict in Agro-Pastoral Context: Issues and Policies (eds Agarwal, P. K. et al.), ICAR, New Delhi, 2016, pp. 1-9.

2. Pathak, B. J., Pati, B. P., Kumar, R., Kumar, A., Raval, P. P., Patel, V. S. and Rana, V. J., Biodiversity Conservation Plan for Gir. Supplementary Management Plan, 2002, p. 407.

3. Vijayan, S. and Pati, B. P., Impact of changing cropping pattern on man-animal conflicts around Gir P.A. with specific reference to Talala Taluka. Indian For., 2001, 127, 1121-1133.

4. Meena, V., 'Site'ing the right reasons: critical evaluation of conservation planning for the Asiatic lion. Eur. J. Wildl. Res., 2010, 56, 209-213.

5. Agrawal, P. K., Vergese, A., Radhakrishna, S. and Subaharan, K., Human-wildlife conflict. Curr. Sci., 2016, 111, 1581-1582.

6. Sih, A., Ferrari, M. C. O. and Harris, D. J., Evolution and behavioural responses to human-induced rapid environmental change. Evol. Appl., 2011, 4, 367-387.

7. Horgan, F. G., Kudavidanage, E. P., Weragodaarachchi, A. and Ramp, D., Traditional 'maavee' rice production in Sri Lanka: environmental, economic and social pressures revealed through stakeholder interviews, Paddy Water Environ., 2018, 16(2), 225241.

8. Robb, G. N., McDonald, R. A., Chamberlain, D. E. and Bearhop, S., Food for thought: supplementary feeding as a driver of ecological change in avian populations. Front Ecol. Environ., 2008, 6, 476-484.

9. Sengupta, A., McConkey, K. R. and Radhakrishna, S., Primates, provisioning and plants: impacts of human cultural behaviours on primate ecological dunctions. PLOS ONE, 2015, 10(11), e0140961.

10. Sengupta, A. and Radhakrishna, S., The hand that feeds the monkey: mutual influence of humans and rhesus macaques (Macaca mulatta) in the context of provisioning. Int. J. Primatol., 2018, 39, $817-830$.

11. Gilroy, J. J. and Sutherland, W. J., Beyond ecological traps: perceptual errors and undervalued resources. Trends Ecol. Evol., 2007, 22, 351-356. 
12. Clergeau, P., Mennechez, G., Sauvage, A. and Lemoine, A., Human perception and appreciation of birds: a motivation for wildlife conservation in urban environments of France. In Avian Ecology and Conservation in an Urbanizing World (eds Marzluff, J. M., Bowman, R. and Donnelly, R.), Springer, Boston, Massachusetts, USA, 2001, pp. 77-96.

13. Carpenter, L. H., Decker, D. J. and Lipscomb, J. F., Stakeholder acceptance capacity in wildlife management. Hum. Dimens. Wildl., 2000, 5, 5-19.

14. Burton, M. and Burton, R., International Wildlife Encyclopedia, Marshall Cavendish, New York, USA, 2002.

15. Ganesan, R., National bird and a state animal - a nuisance in Goa, 2016; https://www.downtoearth.org.in/wildlife-and-biodiversity

16. Naughton-Treves, L., Farming the forest edge: vulnerable places and people around Kibale National Park, Uganda. Geogr. Rev., 1997, 87, 27-46.

17. Treves, A., Wallace, R. B., Naughton-Treves, L. and Morales, A., Co-managing human-wildlife conflicts: a review. Human Dimens. Wildl., 2006, 11, 383-396.

18. Graham, D. M., Notter, B., Adams, W. M., Lee, P. C. and Ochieng, T. N., Patterns of crop-raiding by elephants, Loxodonta africana, in Laikipia, Kenya, and the management of humanelephant conflict. Syst. Biodivers., 2010, 8, 435-445.

19. Mathur, V. B., Kaushik, M., Bist, S. S., Mungi, N. A. and Qureshi, Q., Management of human-wildlife interaction and invasive alien species in India. Report no. TR 2015/004, Wildlife Institute of India, Dehradun, 2015, pp. 1-235.

20. Perera, M. and Vandercone, R., Patterns and perceptions of wildlife crop raiding in and around the Kaludiyapokuna Forest Reserve in the dry zone of Sri Lanka. In Proceedings of the Third Undergraduate Research Symposium on Zoology and Environmental Management, University of Kelaniya, Sri Lanka, 2017.

21. Chauhan, N. P. S. and Singh, R., Crop damage by over abundant populations of Nilgai and blackbuck in Haryana (India) and its management. In Proceedings of the Fourteenth Vertebrate Pest Conference, University of Nebraska-Lincoln, USA, 1990.

22. Chauhan, N. P. S., Barwal, K. S. and Kumar, D., Human-wild pig conflict in selected states in India and mitigation strategies. Acta Silv. Lign. Hung., 2009, 5, 189-197.

23. Ramkumar, K., Balasundaram, R. and Sarvanamuthu, R., Crop damage by Asian elephants Elephas maximus and effectiveness of mitigating measures in Coimbatore Forest Division, South India. Int. Res. J. Biol. Sci., 2014, 3, 1-11.

24. Meena, M., Agriculture crop damage by antelope (Boselaphus tragocamelus) and management strategies: challenges in India. Int. J. Zool. Stud., 2017, 2, 157-160.

25. Bayani, A., Tiwade, D., Dongre, A., Phatak, R. and Watve, M., Assessment of crop damage by protected wild mammalian herbivores on the western boundary of Tadoba-Andhari Tiger Reserve (TATR), Central India. PLoS ONE, 2016, 11, 1-18.

26. Nair, T. P., The peacock cult in Asia. Asian Folklore Stud., 1974, 33, 93-170.

27. Jacobs, M. H., Vaske, J. J. and Sijtsma, M. T. J., Predictive potential of wildlife value orientations for acceptability of management interventions. J. Nat. Conserv., 2014, 22, 377-383.

28. Jacobs, M. H., Vaske, J. J., Dubois, S. and Fehres, P., More than fear: role of emotions in acceptability of lethal control of wolves. Euro. J. Wildl. Res., 2014, 60, 589-598.

29. Jacobs, M. H. and Harms, M., Influence of interpretation on conservation intentions of whale tourists. Tourism Manage., 2014, 42, 123-131.

30. Jacobs, M. H. et al., Toward a mental systems approach to human relationships with wildlife: the role of emotional dispositions. Hum. Dimens. Wildl., 2012, 17, 4-15.

31. Sathyakumar, S. and Kaul, R., Pheasants. In ENVIS Bulletin: Wildlife and Protected Areas, Galliformes of India (eds Sath- yakumar, S. and Sivakumar, K.), Wildlife Institute of India, Dehradun, 2007, pp. 33-52.

32. Rode, K. D., Chiyo, P. I., Chapman, C. A. and McDowells, L. R. Nutritional ecology of elephants in Kibale National Park, Uganda, and its relationship with crop-raiding behaviour. J. Trop. Ecol., 2006, 22, 441-449.

33. Kamal, K. B., Boug, A. and Brain, P. F., Effects of food provisioning on the behaviour of commensal Hamadryas baboons, Papio hamadryas, at Al Hada mountain in Western Saudi Arabia. Zool. Middle East, 1997, 14, 11-22.

34. Berman, C. M. and Li, J. H., Impact of translocation, provisioning and range restriction on a group of Macaca thibetana. Int. J. Primatol., 2002, 23, 283-397.

35. Ram, S., Venkatachalam, S. and Sinha, A., Changing social strategies of wild female bonnet macaques during natural foraging and on provisioning. Curr. Sci., 2003, 84, 780-790.

36. Hadi, I., Suryobroto, B. and Perwitasari-Farajallah, D. Y. A. H. Food preference of semi-provisioned macaques based on feeding duration and foraging party size. HAYATI J. Biosci., 2007, 14, 13 17.

37. McKinney, T., The effects of provisioning and crop-raiding on the diet and foraging activities of human-commensal white-faced capuchins (Cebus capucinus). Am. J. Primatol., 2010, 71, 1-10

38. El-Alami, A., Lavieren, E. V., Rachida, A. and Chait, A., Differences in activity budgets and diet between semiprovisioned and wild-feeding groups of the Endangered Barbary macaque (Macaca sylvanus) in the Central High Atlas Mountains, Morocco. Am. J. Primatol., 2012, 74, 210-216.

39. Oro, D., Genovart, M., Tavecchia, G., Fowler, M. S. and Martinez-Abrain, A., Ecological and evolutionary implications of food subsidies from humans. Ecol. Lett., 2013, 16, 1501-1514.

40. Becker, D. J. and Hall, R. J., Too much of a good thing: resource provisioning alters infectious disease dynamics in wildlife. Biol. Lett., 2014, 10, 1-5.

41. Altmann, J. and Muruthi, P., Differences in daily life between semi-provisioned and wild-feeding baboons. Am. J. Primatol., 1988, 15, 213-221.

42. Jaman, M. F. and Huffman, M. A., The effect of urban and rural habitats and resource type on activity budgets of commensal rhesus macaques Macaca mulatta in Bangladesh. Primates, 2013, 54, 49-59.

43. Orell, M., Population fluctuations and survival of Great Tits (Parus major) dependent on food supplied by man in winter. Ibis, 1989, 131, 112-127.

44. D’Lima, C., Marsh, H., Hamann, M., Sinha, A. and Arthur, R., Positive interactions between Irrawaddy dolphins and artisanal fishers in the Chilika Lagoon of eastern India are driven by ecology, socioeconomics, and culture. J. Hum. Environ., 2013, 43, 614-624.

ACKNOWLEDGEMENTS. D.P. thanks the Department of Biotechnology, Government of India for funds through the Ramalingaswami Re-entry Fellowship, and Maharashtra Education Society's Abasaheb Garware College, Pune for providing infrastructure and administrative support. We thank late Mr Biswaroop Raha for suggesting field sites in Nashik and Dr Dharmendra Khandal and volunteers of Tiger Watch who extended support for field work in Rajasthan. We also thank the Morachi Chincholi residents for hospitality and support during field work, and Rupesh Gawade, Pranav Mhaisalkar, Ankita Divekar, Akash Dubey and Vedanti Mahimkar for help with on-field data collection.

Received 23 May 2019; revised accepted 27 December 2019

doi: $10.18520 / \mathrm{cs} / \mathrm{v} 119 / \mathrm{i} 4 / 670-679$ 